\title{
The Effectiveness of Book Selection Agents in a Small Academic Library
}

\section{Christopher Millson-Martula}

Small academic libraries typically rely more heavily upon classroom faculty as book selectors than do large academic libraries in which librarians and book jobbers are the principals involved. Given the various constraints that small academic libraries face, it is important for them to rationalize the entire collection development process and also to employ the most effective agents as book selectors. This article describes a study of the relative effectiveness of classroom faculty and librarians as book selection agents in a small academic library.

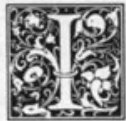

nflation, declining or stable enrollments, revised institutional priorities, curricula, and other factors have resulted in a rethinking of collection management for many academic libraries. In some institutions a specific staff member has been identified as the chief collection development officer with at least coordinating responsibility for all aspects of collection management. In many other institutions approval plans and other methods have been adopted to stretch as far as possible every dollar expended, and greater attention has been given to collection evaluation, especially with regard to periodical subscriptions. The overall result for many academic libraries has been a greater, more intense focus on collection development and an elevation of collection management as a specialty area to a level approaching that of public services and technical services. If library literature is an accurate indicator, the majority of significant collection management activity is occurring in a large academic and research libraries. However, as the study described in this article indicates, significant collection management activity is also occurring in small academic libraries-collections with fewer than 200,000 volumes and annual materials budgets of less than $\$ 150,000$.

Regardless of the size of an academic library, relatively little attention has been given to the question of who can most effectively select materials for the collection. This lack of attention to the effectiveness of selection is especially surprising since a collection constitutes a large investment in dollars, time, and space, and any practical administrator should determine not only the rate of return on that investment but also should investigate the quality of the investment decisions that are made. In small academic libraries, the two groups most often responsible for selection are classroom faculty and librarians. Does one group of selectors, either classroom faculty or their librarian colleagues, generally make more effective collection decisions than the other?

\section{THE SETTING}

The library described in this study serves an urban commuter college located in Chicago. Approximately two thousand students are enrolled in both traditional liberal arts courses and career-related programs in areas such as business, criminal 
justice, education, and nursing. In addition to offering courses at the undergraduate level, the college also offers some career-related programs at the master's level.

The library collection consists of approximately seventy-five thousand volumes and four thousand volumes are added annually. Membership in two consortia, in addition to OCLC, provides direct access to almost ten million volumes. The materials budget for both books and periodical subscriptions is about $\$ 100,000$, with allocations for book purchases in various subject areas based on a mathematical formula in which use (both external and internal) and average cost per book are the principal elements. Although funds for library acquisitions are allocated to the library budget, the individual allocations for subject areas are jointly administered by the library and the appropriate academic departments until April 1 of each year, after which time all funds not yet spent or encumbered are administered solely by the library.

Responsibility for selection of materials is shared by the classroom faculty and the three reader services librarians. Each reader services librarian has two master's degrees and has liaison, library instruction, and collection development responsibilities in one of three broad areas (humanities, natural sciences, and social sciences). Both librarians and classroom faculty initiate requests. When a librarian makes a selection before April 1, the librarian forwards the order card to the appropriate academic department head, who, in turn, may authorize the request and forward it to the library for purchase. Although the extent of librarian involvement in the selection process varies from one subject area to another, the number of requests initiated by a librarian rarely drops below 40 percent of the total requests in a given subject area.

\section{THE STUDY}

This was a conventional study of the use of the history section of the collection, including all countries and all time periods. Only the history section of the collection was chosen because it was one of but three subject areas in which a librarian held a second master's degree. Consequently, selection by the librarian should have been done at a relatively high level of competence. The investigation was limited to books, including both monographs and serials, but not periodicals. Unlike a conventional use study, however, this investigation did not assess the use of materials added to the collection but rather investigated the relationship between use and selection responsibility.

\section{Hypotheses}

The study was designed to test two hypotheses:

1. History books selected by classroom faculty show greater circulation activity (a greater number of circulations per book) than those selected by their librarian colleagues.

2. History books showing circulation activity (at least one circulation per book) have a higher level of activity during the first three years of inclusion in the collection than in later years.

For many years, the history section of the collection has constituted a relatively little-used part of the collection, contributing an average of no more than 4 percent of the total circulation activity. History faculty members frequently recommend specific book titles to students for research papers and other library-related classroom assignments; therefore, it was assumed that history books selected by history faculty would have a greater amount of circulation activity than those selected by librarians.

The Kent study at the University of Pittsburgh and other studies in academic libraries revealed that books are most likely to show circulation activity within the first three years of their addition to the library collection. ${ }^{1}$ After this period, use drops off considerably or ceases. Items showing no circulation activity during the first three years following acquisition are not likely to have any activity in following years. Based upon the investigator's experience, there were no factors likely to make the local situation different from other academic situations. A review of the 
literature follows the discussion of the study.

\section{Data Collection and Analysis}

The study focused on those 691 history books that were added to the collection during the period July 1,1977 , through June 30,1980 . Evaluation of their use covered the period between July 1, 1977, and June 30, 1983. For each book, two types of data were collected: status of selector (classroom faculty or librarian) and amount of external use (as measured by recorded circulation transactions).

The selector's status was easily determined by noting the name of the requestor on the order card for each item ordered during the data collection period. The amount of external use was determined by two methods, one for uses before October 1980 and one for uses after that date. Until October 1980, the library used a manual circulation system. To determine uses that occurred before October 1980, the date due slip in each of the books involved in the study was checked for circulation activity. When a book was not on the shelf at the time of the data collection, the stacks were rechecked two months later. If, at that time, the book was still unavailable for examination, it was dropped from the study. In October 1980, when the library joined the Library Computer System (LCS), an automated circulation system and resource-sharing network, the library discontinued its use of date due slips, relying instead upon a date due card that was valid for one circulation only. To determine uses that occurred after October 1980, the circulation activity for each item involved in the study was generated from LCS circulation records. The transition from a manual to an automated circulation system served a useful purpose in that it provided a clear line of demarcation that could be used in easily determining what effect, if any, the length of time an item had been in the collection had upon its circulation activity.

The data were analyzed in order to determine the relationship between use and selector, especially the relative effectiveness of the two selector groups, and that between use and the length of time an item had been in the collection. It was determined that the chi square test applied to a $2 \times 2$ contingency table at the .01 level of significance could be used effectively to test the study's first hypothesis.

\section{Results}

During the three-year acquisition period covered by the study, 691 books were added to the collection and charged to the history fund. Librarians selected the great majority of books, a total of 523 books or 75.69 percent, that were added to the collection during the study; classroom faculty selected 168 books or 24.31 percent of the total. Although the total number of books selected in each of the three years ranges from a high of 420 to a low of 87 , the low can be considered typical for a year during which 4,000 books are added to the collection. The number of books added during the first two years of the study was significantly higher due to retrospective collection development based in large part upon the second edition of Books for College Libraries.

It is not unreasonable to assume that in many academic libraries history materials receive high use due to the nature of the information transfer process in history and the widespread prevalence of course assignments requiring library use. According to the data collected in this study, however, history materials constituted no more than 4 percent of total circulation activity in each of the years covered by the study. Of the 691 books added to the collection, only 420 books or 60.78 percent showed any circulation activity. The total number of circulation transactions was 1,176 or 1.70 circulations per book for all books added and 2.80 circulations per book for all books having at least one circulation transaction. Tables 1 and 2 provide more detailed information about circulation activity for books selected by each group of selectors. The data seem to indicate that in terms of circulation per book classroom faculty make more effective book selectors than their librarian colleagues. In table 3 the results are presented in a slightly different way. This table indicates equal effectiveness in selection activity on the part of classroom 
TABLE 1

CIRCULATION ACTIVITY FOR BOOKS SELECTED BY CLASSROOM FACULTY

\begin{tabular}{lcccc}
\hline \hline Year & $\begin{array}{c}\text { Books } \\
\text { Circulated }\end{array}$ & $\begin{array}{c}\text { Book } \\
\text { Circulations }\end{array}$ & $\begin{array}{c}\text { Circulations } \\
\text { per Book } \\
\text { for All } \\
\text { Books Added }\end{array}$ & $\begin{array}{c}\text { Circulations } \\
\text { per Book } \\
\text { for Books } \\
\text { Circulated }\end{array}$ \\
\hline $1977-78$ & 54 & 183 & 2.23 & 3.39 \\
$1978-79$ & 36 & 121 & 1.95 & 3.36 \\
$1979-80$ & 14 & 29 & 1.21 & 2.07 \\
Composite & 104 & 333 & 1.98 & 3.20 \\
\hline
\end{tabular}

TABLE 2

CIRCULATION ACTIVITY FOR BOOKS SELECTED BY LIBRARIANS

\begin{tabular}{lcccc}
\hline \hline Year & $\begin{array}{c}\text { Books } \\
\text { Circulated }\end{array}$ & $\begin{array}{c}\text { Book } \\
\text { Circulations }\end{array}$ & $\begin{array}{c}\text { Circulations } \\
\text { per Book } \\
\text { for All } \\
\text { Books Added }\end{array}$ & $\begin{array}{c}\text { Circulations } \\
\text { per Book } \\
\text { for Books } \\
\text { Circulated }\end{array}$ \\
\hline $1977-78$ & 203 & 557 & 1.65 & 2.74 \\
$1978-79$ & 75 & 217 & 1.78 & 2.89 \\
$1979-80$ & 38 & 69 & 1.10 & 1.82 \\
Composite & 316 & 843 & 1.61 & 2.67 \\
\hline
\end{tabular}

TABLE 3

BOOKS CIRCULATED AS A PERCENTAGE OF BOOKS SELECTED

\begin{tabular}{lccc}
\hline \hline Selector & Books Selected & Books Circulated & $\begin{array}{c}\text { Books Circulated as a } \\
\text { Percentage of Books } \\
\text { Selected }\end{array}$ \\
\hline Classroom faculty & 168 & 104 & 61.90 \\
Librarians & 523 & 316 & 60.42 \\
\hline
\end{tabular}

faculty and librarians. Whether or not this would still be the case if retrospective acquisitions (those books selected from Books for College Libraries) were removed from the study remains to be seen. However, the Pittsburgh study shows that current publications receive greater use than those purchased on a retrospective basis. ${ }^{2}$ Unfortunately, retrospective acquisitions were not singled out during the study.

Two other analyses were deemed appropriate for the study: (1) the percentage relationship between selectors and books selected, number of titles circulated, and total number of circulations; and (2) the relationship between selector and single versus multiple circulation transactions. Table 4 indicates that while both groups of selectors may be equally effective in terms of circulation activity, classroom faculty make a greater contribution in terms of selecting books that have multiple circulation transactions. This is confirmed by table 5 . These data also indicate that librarians may be selecting those books more likely to be used by either nonhistory students or history students who do not consult with their instructors for relevant sources. Although there are no relevant data available, perhaps one can assume that the selections of librarians added breadth to the collection while the selections of classroom faculty tended to provide the collection with a greater degree of depth in relatively few subject areas.

While these analyses of the data provide valuable insights into the relationships among categories of selectors, books selected, and books circulated, other analyses were needed to test the research hypotheses. To test the first hypothesis, a $2 \times 2$ contingency table was created, and the chi square test was used. With one degree of freedom, a chi square value beyond 6.635 is statistically significant at the .01 level. Since the resultant chi square value was .0000085 , the first hypothesis was rejected.

The second part of the study involved 
TABLE 4

RELATIONSHIP BETWEEN SELECTOR AND ACQUISITIONS AND CIRCULATION ACTIVITY IN PERCENTAGES

\begin{tabular}{lccc}
\hline \hline Selector & Books Selected & Books Circulated & Book Circulations \\
\hline Classroom faculty & 24.31 & 24.76 & 28.32 \\
Librarians & 75.69 & 75.24 & 71.68 \\
\hline
\end{tabular}

TABLE 5

SINGLE VERSUS MULTIPLE CIRCULATIONS BY SELECTOR

\begin{tabular}{|c|c|c|c|c|}
\hline \multirow[b]{2}{*}{ Selector } & \multicolumn{2}{|c|}{ Books Circulated Once } & \multicolumn{2}{|c|}{ Books Circulated More Than Once } \\
\hline & $\begin{array}{l}\text { Number } \\
\text { of Books }\end{array}$ & $\begin{array}{c}\text { Percentage of } \\
\text { Books Circulated }\end{array}$ & $\begin{array}{l}\text { Number } \\
\text { of Books }\end{array}$ & $\begin{array}{c}\text { Percentage of } \\
\text { Books Circulated }\end{array}$ \\
\hline Classroom faculty & 30 & 28.85 & 74 & 71.15 \\
\hline Librarians & 125 & 39.56 & 191 & 60.44 \\
\hline
\end{tabular}

an analysis of circulation activity before and after the library's transition from a manual to an automated circulation system. While analyzing circulation before and after October 1980 may be considered primitive because it did not allow for a uniform time period under each circulation system, the change in systems nonetheless provides a demarcation line for determining use in the recent and distant pasts.

Under both circulation systems it is expected that items not used in the first three years after their addition to the collection are not likely to be used in succeeding years. Approximately 38.8 percent of the books were not used at all. When one combines the books not used at all with those books with a decrease in use under the automated circulation system ( 71 percent for 1977-78 books, 68.5 percent for 1978-79 books, and 52.9 percent for 1979-80 books), it seems that for this particular collection the majority of books have little or no value to users after a relatively short period of time. Table 6 provides more detailed information.

While about 30 percent of the books showed decreased circulation activity un- der the automated system, about 25 percent of the books experienced increased use; the 41.5 percent increase for $1979-80$ books is probably artificially high since most of these books did not have the opportunity for significant circulation activity under the manual circulation system.

While the number of total book circulations and of titles circulated decreased under the automated circulation system compared to the manual system, this was not consistently true for the first two years of the study (see tables 7 and 8 which contain data for books circulated under both circulation systems). Although the increase for $1979-80$ books under the automated circulation system is quite expected due to the brief period of time those books were available for circulation under the manual system, the same cannot be said for the increase demonstrated by the 1978-79 books. Thus, since the data indicate inconclusive results, the second hypothesis cannot be supported.

\section{COMPARATIVE DATA}

How do the results of this study compare to data gathered at similar institu-

TABLE 6

CHANGE IN CIRCULATION ACTIVITY FROM FIRST TO SECOND CIRCULATION SYSTEM AS A PERCENTAGE

\begin{tabular}{lcccr}
\hline \hline Year of Acquisition & Increase & Decrease & Some Use & No Change \\
\hline $1977-78$ & 23.56 & 32.86 & 5.48 & No Use \\
$1978-79$ & 27.17 & 29.35 & 4.35 & 38.10 \\
$1979-80$ & 41.35 & 13.80 & 5.75 & 39.13 \\
\hline
\end{tabular}


TABLE 7

CIRCULATION ACTIVITY UNDER MANUAL SYSTEM

FOR BOOKS CIRCULATED UNDER BOTH CIRCULATION SYSTEMS

\begin{tabular}{lccc}
\hline \hline Year & $\begin{array}{c}\text { Book } \\
\text { Circulations }\end{array}$ & $\begin{array}{c}\text { Books } \\
\text { Circulated }\end{array}$ & $\begin{array}{c}\text { Circulations per Book } \\
\text { for Books Circulated }\end{array}$ \\
\hline $1977-78$ & 427 & 192 & 2.22 \\
$1978-79$ & 157 & 75 & 2.09 \\
$1979-80$ & 25 & 18 & 1.39 \\
\hline
\end{tabular}

TABLE 8

CIRCULATION ACTIVITY UNDER AUTOMATED SYSTEM

FOR BOOKS CIRCULATED UNDER BOTH CIRCULATION SYSTEMS

\begin{tabular}{lccc}
\hline \hline Year & $\begin{array}{c}\text { Book } \\
\text { Circulations }\end{array}$ & $\begin{array}{c}\text { Books } \\
\text { Circulated }\end{array}$ & $\begin{array}{c}\text { Circulations per Book } \\
\text { for Books Circulated }\end{array}$ \\
\hline $1977-78$ & 315 & 157 & 2.01 \\
$1978-79$ & 180 & 80 & 2.25 \\
$1979-80$ & 72 & 42 & 1.71 \\
\hline
\end{tabular}

tions? A review of the literature indicates that smaller academic libraries are not undertaking studies of the relationship of book use and book selector responsibility, or, if they are, the results are not being broadly disseminated to the profession.

The author located only one similar study, and it was but one portion of a broader DePauw University study that partially replicated the 1978 University of Pittsburgh library materials study. ${ }^{3}$ Larry Hardesty studied the circulation activity of slightly more than 1,700 books selected by both librarians and classroom faculty. Librarian selections constituted only 173 of the total. The results led Hardesty to conclude that "librarians can play a useful role in the selection of books for the academic library. ${ }^{\prime 4} \mathrm{He}$ found that 31.2 percent of librarian-selected books were not used at all, while the comparable figure for books selected by classroom faculty was 34.2 percent. In addition, his results indicated that librarian-selected books constituted a higher than expected portion of books with moderate or heavy use (more than six circulations). Hardesty concludes that "the main difference between the classroom instructor-selected books and librarian-selected books is that the librarians selected fewer graduate level books in narrow specialties."

Although the Hardesty study seems to be the only reported study of book use and selection responsibility in a small aca- demic library, several such studies have been conducted in university libraries. A landmark study was conducted by Gayle Edward Evans at four public and private university libraries located in the Midwest and the Rocky Mountain region during the 1960 s. $^{6}$ His study involved an examination of circulation activity in relation to selection agent: librarian, classroom faculty, or book jobber. Evans hypothesized that selection agents having the greatest number of contacts with the greatest number of library users would select the highest percentage of titles showing circulation activity. To test this hypothesis Evans studied the circulation of 6,891 titles (English-language current imprint monographs) based on a random sample of at least 500 titles per type of agent per institution. Analysis of circulation activity covered the first twelve months of availability in the collection. The study results confirmed part of Evans' hypothesis, namely, that librarians tended to select the greatest number of materials that were used; faculty and jobbers followed. However, Evans apparently did not feel sufficiently confident to attribute the librarians' performance to their extensive contact with library users. At first, he thought that the differences between librarians and faculty arose from different selection philosophies. Later he stated that both types of agents appeared to be selecting from the same philosophical point of view. Unable 
to make any definitive statement, Evans concluded with an expression of need to determine the cost-benefit factors for each type of selection agent.

Robbie Bingham carried out a similar study approximately ten years later at four university libraries in the South. ${ }^{7}$ While Bingham also investigated the relationship between categories of selectors and use of selected items, she added two categories of selection agents to Evans' three: faculty/jobber and librarian/jobber. Sampling 7,224 titles (450-500 items for each single category of selection agent and at least 100 items for each of the two combination categories), Bingham hypothesized the following descending order of use by selection agent: (1) faculty/jobber; (2) librarian/jobber; (3) faculty; (4) librarian; and (5) jobber. Bingham found that the single categories of selection agents were more effective than the combination categories, with faculty selecting the greatest number of materials used. However, for materials dealing with the humanities, librarians replaced faculty as the most effective selection agent.

\section{CONCLUSION}

It is not surprising that the results of the studies cited above are not uniform. Perhaps the factors exercising the greatest in- fluence are key institutional characteristics-curricula, library, faculty, and students-that are unique to each institution.

It is also not surprising that a great deal of work remains to be done before academic libraries, especially smaller academic libraries, can establish collection development processes that are appropriate for meeting users' demonstrated needs. In order to do so, considerable analysis needs to be done concerning selection agents. Factors such as educational background, relevant experience, philosophy of selection, and sources or methods used for selection (together with the related costs involved) have a direct bearing on the effectiveness of collection development. Likewise, selections should be analyzed in terms of those pre-acquisition indicators that Weeks claims predict book use: type of publisher, language of publication, date of publication, and type of publication (single or multiple author, conference proceedings, serial reviews, and bibliographies). ${ }^{8}$

What can be said with a reasonable degree of certainty is that librarians play a significant role in book selection. The goal remains, however, to enhance that role in a way that will make collections more relevant to curricular or research needs.

\section{REFERENCES}

1. Allen Kent and others, Use of Library Materials: The University of Pittsburgh Study (New York: Dekker, 1979).

2. Ibid.

3. Larry Hardesty, "Use of Library Materials at a Small Liberal Arts College," Library Research 3:261-82 (Fall 1981).

4. Ibid., p. 275 .

5. Ibid.

6. Gayle Edward Evans, "The Influence of Book Selection Agents Upon Book Collection Usage in Academic Libraries"' (Ph.D. diss., Univ. of Illinois, 1969).

7. Robbie B. Bingham, "Collection Development in University Libraries: An Investigation of the Relationship Between Categories of Selectors and Usage of Selected Items" (Ph.D. diss., Rutgers Univ., 1979).

8. Kenneth Weeks, Determination of Pre-acquisition Predictors of Book Use (Berkeley, Calif.: Institute of Library Research, Univ. of California, 1973). 